\title{
Paper Title: Entangled Histories: Iron Ore Mining in Canada and the United States
}

\author{
Dr. John Thistle ,Professor Nancy Langston
}

Labrador Institute of Memorial University 219 Hamilton River Road P.O. Box 490, Stn. B Happy Valley-Goose Bay, NL A0P 1E0 1-709-497-3630 ext. 222 jthistle@mun.ca Michigan Technological University Department of Social Sciences 209 Academic Office Bldg, GLRC 220 Houghton, MI 49931 nelangs3@mtu.edu

Corresponding author: John Thistle Labrador Institute of Memorial University 219 Hamilton River Road P.O. Box 490, Stn. B Happy Valley-Goose Bay, NL A0P 1E0 1709-497-3630 ext.222 jthistle@mun.ca

\section{Abstract}

This paper examines the entangled histories of post-WW2 iron ore mining in the QuebecLabrador region of the Canada and the Lake Superior basin of the United States. After a brief look at the scale of iron mining in Labrador, we examine the so-called "Iron Ore Dilemma" in the United States - the fears that dwindling supplies of high-grade iron ore in the Lake Superior District threatened Cold War strategic interests. Using the case study of Reserve Mining Company along Minnesota's north shore, we examine how cold war concerns about the depletion of direct shipping ore led American mining interests to promote the technologies and tax incentives needed to exploit taconite ore bodies-a lower-grade iron ore that required new technologies and created new environmental consequences. We then turn to the Canadian subarctic where American iron and steel interests worked with Canadian partners and the state to establish mines that might replace depleted ores in the Lake Superior Basin. Tracing the webs of connections between Quebec-Labrador and the Lakes Superior Basin illuminates the ways that transboundary processes draw distant mining regions together. It also illustrates how the effects of mining extend beyond the mine site, crossing scales of time and space. 
Keywords: iron mining, Lake Superior, Labrador, taconite, pollution, environmental history

\section{Introduction}

In the eastern Canadian subarctic, massive iron mines lie along the Quebec-Labrador border, tapping the rich iron resources of the $1600 \mathrm{~km}$-long Labrador Trough, a structure of sedimentary and volcanic rocks deposited two billion years ago under a shallow sea. ${ }^{1}$ Total annual production of refined ore from the Quebec-Labrador region is roughly 40 million tons - essentially all of Canada's production. In a global context, this places Canada ninth in global iron ore production, just below the United State's 52 million tons, and well below China's 1.32 billion tons (USGS 2014).

This is a lot of iron ore. But all this ore has been extracted from industrial installations (including pits, supply roads, and tailings piles) that occupy a relatively small area. The two largest iron mining operations in Canada, IOC in Labrador (11,000 ha) and ArcelorMittal in Quebec (6216 ha), only account for about $0.00002 \%$ of the Canadian land base. At first glance, so much ore from so small an area underscores the mining industry's image of itself as an industry that has primarily local effects, disrupting "small areas of land for short periods of time,"(Wynn 2007, 332). Even if we added every metal mine developed in Canada over the last 150 years, the area would total only 0.03 percent of Canada's land mass, an area not even half the size of the country's smallest province (Wynn 2007).

\footnotetext{
${ }^{1}$ Labrador is part of the Canadian province of Newfoundland and Labrador. For brevity, unless otherwise noted, we will simply refer to Labrador rather than Newfoundland and Labrador.
} 
Mines are often located far from urban centers, creating a sense of remoteness (at least in the eyes of decision-makers), which reinforces a sense that the environmental effects of mines are fairly limited. Mining interests promote this view of their activities-the effects of digging a massive hole in the ground and extracting ore might seem severe, but in the global context, those effects are quite local. But this is a conceit. Mines may seem remote and their ecological effects limited, but this paper argues that such perceptions are illusions that obscure important connections. Rather than being remote and selfcontained, flows of power, capital, and technology have connected iron mines in the Lake Superior District and the Labrador Trough of North America.

This paper will trace the webs of connections between Quebec-Labrador and the Lakes Superior basin, starting with iron mining in Lake Superior region, where concerns about depletion of high-grade iron ore stimulated two key changes: a shift to mining of lowergrade taconite ore, and a strategic move to promote iron ore mining in Quebec-Labrador. Both of these regions are extractive peripheries, and they manifest similar complex connections to far flung, but geographically specific, networks and processes of extraction and dispossession, environmental transformation, and accumulation (Barnes, Hayter, and Bradshaw 2003) As sites located at the northern edge of each country, both regions illustrate the ways that the north has been shaped by rich entanglements between environmental history, politics, and technology (Jorgensen and Sorlin 2013). Comparing the two regions illustrates the ways that transboundary processes draw distant mining regions together, while also illuminating how the effects of mining extend well beyond the mine site, crossing scales of time and space. 


\section{The Iron Ore Dilemma in the US}

American economic expansion after the Second World War required steel, and steel manufacturing required reliable sources of iron ore. But what if domestic supplies of high-grade iron ore were rapidly depleting? In a December 1945 article on the "Iron Ore Dilemma" in the United States, Fortune Magazine posed just this question. It began by asking readers to imagine a diagram in which the American economy appeared as an "immense inverted pyramid, its needle base resting on a single strip of gently rolling land, 110 miles long by one to four miles wide, in North Minnesota." Out of this small "strip" of land, "the steel age economy" of America had "sucked like milk from the earth mother's breast, by far the largest portion of the principle food out of which its bones and muscles have been built: its machines and tools, its buildings and bridges, its railroads and automobiles, its generating plants." As the key ingredient in manufactured iron and steel, the iron ore from this remote region made possible automobiles, railroads, skyscrapers, barbed wire, tanks, bombs and bullets (Manners 1971). Even more important in light of recent global conflicts, the region had supplied the nation's weapons and war machines: "Blasted and gouged from the strip's awesome open pits," were fully "twothirds of the iron ore for the 400-odd million tons of steel out of which the United Stated had fashioned the war plants, ships, planes, tanks, guns, bombs, and shells of World War II," ("The Iron Ore Dilemma" 1945, 129).

The iron ranges of Minnesota, Wisconsin, and Michigan--collectively known as the Lake Superior District--had "nourished the US economy for half a century, through two World Wars" ("The Iron Ore Dilemma," 1945, 129). Yet the region was slow to develop, because Lake Superior's distance from North American centers of industrialization posed 
a critical problem before the Civil War. However rich the ore bodies, rapids and other natural obstacles made the cost of transporting ore from mines to markets prohibitive. Federal involvement in the creation of a shipping and railroad infrastructure within the Great Lakes, starting with the 1855 construction of Sault St. Marie locks, was key to overcoming the problem of remoteness and distance, thus enabling development of the Lake Superior District (Bowlus 2010, Reynolds and Dawson 2011). By 1890 more than half the of all the iron ore used by the American iron and steel industry came from the Lake Superior District (Figure 1). At the end of the second world war, the region supplied 85 percent of the United States' supply of iron ore (Harrison 1953).

Iron ore in the Lake Superior basin fell into two broad types: high-grade ores (often called "direct shipping ores" because such ores required minimal processing before shipping), and low-grade ores which required expensive beneficiation: an expensive and technically challenging process involving crushing, screening, grinding, magnetic separation, filtering and finally drying (Manuel 2013, LeCain 2009). Before the 1950s, iron mining in the Lake Superior Basin focused on higher-grade hematite (50 to 70\% iron) that did not have to be beneficiated. Increased steel output during the Second World war, however, meant that much of the Lake Superior region's accessible high-grade iron ore had been extracted, leaving lower-grade taconite ores that, while abundant, appeared quite difficult to mine at a profit. Fortune Magazine warned that the iron ore dilemma in the United States came down to two interrelated questions. First, how long could the Lake Superior District compete with high-grade ores from politically unstable countries such as Brazil and Venezuela? Second, could the United States "risk the prospect of another war without a large and quickly available stock-pile of iron ore or pig iron?" 
("The Iron Ore Dilemma" 1945, 129). The solution, Fortune argued, was two-fold: figure out how to process cheaply the lower-grade taconite deposits that remained in the Lake Superior region, and invest in the development of certain iron ore deposits abroad, while protecting those investments from political upheaval.

\section{The Shift to Low Grade Deposits: Taconites and the Lake Superior District}

Between 1896 and 1900, the American steel industry had experienced a radical transformation. Small companies had given way to large steel corporations that controlled not just steel mills, but also the iron mines that supplied those mills (Reynolds and Dawson 2011). Nearly three quarters of all Lake Superior iron ore in 1900 came from mines that were "either owned by or under long-term lease" to the largest American steel companies: Carnegie Steel, Federal Steel, National Steel and several others—all to be absorbed into US Steel in 1905 (Mancke 1972, 222). In 1947, Reserve Mining Company-under the ownership of Armco Steel Corporation and Republic Steel Corporation--applied for permits to process taconite on the shores of Lake Superior near the small community of Silver Bay. Lake Superior would supply both the abundant water needed for taconite processing and a convenient location for tailings disposal. The company initially requested permits to deposit about 67,000 tons of tailings each day into the lake-eventually totaling 400 million tons of tailings. Once the mine reached full capacity, it produced $11 \%$ of the country's total iron production and revitalized the faltering mining economy of the Lake Superior district (Berndt and Brice 2008). Mining taconite required extensive technological and financial investments in beneficiation, an energy and water-intensive process. With the development of taconite, 
mining for iron ore was to become less a simple matter of extracting valuable ore from the ground, and far more a case of manufacturing production. As Reserve Mining company officers told the hearing commission in 1947, "The entire process of mining, crushing, fine grinding and sintering or agglomerating [taconite] is an extremely complicated and costly process.....Essentially it is a manufacturing industry rather than mining; the manufacture of a useable iron ore from materials which are absolutely worthless in the ground.” (emphasis added; Reserve Mining Company 1947, 3). By 1950, engineers were insisting that hematite depletion in the Lake Superior District demanded new government investments, new tax policies, and relaxed environmental standards in order to ensure American national security. In 1947, Reserve argued that "If the process can be developed on a commercial scale it means an almost unlimited source of iron ore for generations to come, since the quantities of taconite are large enough to support such an industry for an indefinite time in the future. It means that Minnesota will have an iron ore industry for generations to come instead of for a limited period of time." (Reserve Mining Company 1947, 3). During permit hearings for the Reserve Mine's processing facility, mine owners echoed the language of Fortune Magazine, stating that "The heavy war shipments have greatly depleted the reserves of these companies.... Several of them have - acquired and are considering the development of large holdings in Chili, Venezuela, Cuba, Labrador Canada and other foreign countries....However, because of the location of their principal steel plants on the lower Great Lakes, most of these companies would very much prefer to develop a long-time source of iron ore supply in the area around Lake Superior. Furthermore, the development of large reserves in this area is recognized to be of national importance because a serious 
problem of national security is presented if the steel industry is dependent upon foreign sources for its iron ore.” (Reserve Mining Company 1947, 3-4).

In mining regions around the globe, engineers and metallurgists had developed techniques to efficiently and profitably recover metals from low-grade ores. Yet engineers like Minnesota's Edward Davis, who spent much of his career promoting taconite, understood that this was more than just a technical challenge. It was also political one. In a sense the mining industry had to reinvent itself but this would be done easily. With this in mind, Davis lobbied the Minnesota legislature for tax changes that would encourage taconite processing by reducing the taxes that taconite companies paid. In particular, taxes directed toward local communities would be cut (Manuel 2013). In 1964, Minnesota passed the "Taconite Amendment" which adopted a tax code that shifted more of the costs of mining to communities and the profits to industry (Kakela 1978). These new laws did what engineering alone could not do: allow taconite production to boom. As soon as the tax laws were revised, companies moved to create the infrastructure that would enable them to tap the vast taconite reserves along Minnesota's north shore.

As Timothy LeCain (2009) argues in Mass Destruction, the development of open pit mining for low-grade ores became dominated by large corporations using enormous machines to extract low-grade deposits from open pits. Mining companies, state governments, and local communities recognized that developing these ore bodies would pose significant new environmental challenges (see, for example, statements by Reserve Mining Company lawyer Mr. Montague during the initial permit hearings; Montague 1947). In a 1950 issue of Science Newsletter, the journalist Ann Ewing admitted that 
taconite development had significant environmental costs-particularly given that 48 tons of water would be needed for every ton of iron produced. Moreover, "the disposal of tailings presents a problem. They could be dumped on the ground, but it would take vast areas to accommodate them," (Ewing 1950, 315). To make the processing of taconite feasible, Reserve required over 500,000 gallons of water per minute from Lake Superior, and would need to dump about 67,000 tons of tailings each day into the lake-eventually totaling 400 million tons of tailings. The environmental consequences could be significant, and Reserve Mining Company addressed those questions directly before state regulators.

Before granting permits in 1947, the state of Minnesota held an extensive series of hearings to decide whether taconite mining, processing, and tailings disposal would be safe for Lake Superior. Thousands of pages of testimony reveal that regulators, companies, and communities took possible environmental threats quite seriously_ just as they took the potential national security benefits quite seriously as well. Fishermen from communities along Minnesota's north shore expressed concerns that tailings and water withdrawals might devastate fish habitat and ruin their economic base, while other citizens testified about their fears that silica in the tailings might lead to silicosis. Regional and national conservation groups testified against the plans for lake disposal of tailings. Nearly a thousand petitions opposing the plant were gathered. Even most labor groups in Duluth were strongly opposed to the proposed tailings disposal plans, citing conservation concerns in their testimony (Tuskey 1947, 139).

Nevertheless, the state granted permits for the mine to dispose tailings directly into Lake Superior, persuaded by Reserve Mining Company's assurances that tailings would be 
contained in a very small area within the lake itself (Davis, 1947). As consultant engineer Edward Davis argued, the tailings would sink into "deep valleys at the bottom of Lake Superior. There they would be out of sight forever and posterity would not have to cope with them. We assured Reserve that the gray, sandy tailings of magnetic taconite would not in any way pollute the lake, interfere with any domestic water supply or with navigation, and would not adversely affect the fishing industry. It was our conclusion that the fine tailings from all the magnetic taconite on the Mesabi could be put into the deep water of Lake Superior and would have no harmful effect on its usefulness or beauty," (Davis 2004, 128).

The environmental risks were real, the Minnesota Pollution Agency determined, but they would remain quite localized—distant from fishing communities and cities along the lake. The economic and security benefits, however, would ripple throughout the state, the nation, and even the globe (Chesley 1947). Without taconite, the region's economy might collapse; with taconite, a bright future was assured. Mr Montague, lawyer for Reserve, opened his statement before the MN Commissioner of Conservation, in 1947 by stating: "by now everybody realizes that the future of the iron mining industry in the state depends upon whether or not the taconite industry can be developed. The state is in a position where it can see the rapid curtailment of mining operations and the early exhaustion of ores unless they can be supplemented and eventually replaced by the production of ore from taconite (Montague 1947, 6).

Reserve Mining opened the taconite processing facility in 1955, and within two years, complaints from fisherman and local residents about tailings pollution were flooding state regulatory offices. The tailings were not staying contained: reports of green, murky water 
and fouled fishing nets miles away were common (Minnesota Department of Health 1957). When Reserve's tailings were dumped into water, toxics moved out of localized mining spaces and into much more dispersed spaces. The state was slow to respond to these claims, instead allowing the plant to expand twice, doubling its water use in 1956 and again in 1960. Until evidence of human harm emerged two decades later, complaints about pollution were essentially suppressed by state and federal agencies (Stoddard 1968, Zwick and Benstock 1971).

This changed in the early 1970s when evidence was discovered that asbestos fibers were part of the tailings deposited into Lake Superior. Most importantly, abestos fibers had not been contained locally, but had drifted from the disposal site, moving many kilometers south, where they entered the drinking water supply of Duluth, the largest city in the Lake Superior basin. Concern that people might be poisoned by water-borne asbestos mobilized federal and state governments to examine the risks from taconite. On behalf of the federal Environmental Protection Agency, the Department of Justice filed a lawsuit against Reserve in 1973, beginning a trial and appeals processes that would last for a decade. In early June 1973, Judge Miles Lord heard testimony from a specialist in asbestos exposure, Dr. Irving Selikoff, who confirmed that the city's drinking water contained asbestos from the tailings. The concentration was surprisingly high: 100 billion fibers per liter of water, which was at far than any asbestos level previously found in a city water sample (MPCA 1973).

Reserve Mining Company disputed evidence about toxic mobilization, marshaling scientists to present a case that the tailings were still contained; that asbestos could not move from tailing into Lake Superior, from Lake Superior into drinking water, and from 
drinking water into lungs. In an EPA file of evidence presented at the trial on ecological disruption caused by the tailings, Dr. Donald Mount of the EPA provided evidence that Reserve was distorting scientific process. Reserve, Mount claimed, had designed studies with false controls to contaminate any possible findings, and the company took measurements of tailings in places that they knew could not possibly show significant difference from controls (Mount 1973). Moreover, tailings were not contained in the slightest: they had dispersed from the small disposal site into the entire western third of the largest lake in the world.

Taconite mining in Lake Superior District mobilized toxic chemicals that moved into local bodies-particularly the lungs of miners, where workers on the iron range were three times as likely to get mesothelioma as the general population (Lourey et al. 2013). Toxics also moved into much broader watersheds, as the Reserve case shows. Recent research shows as well that taconite processing released (and continued to release) significant quantities of atmospheric mercury, which is now the largest within-basin source in Lake Superior. That same mercury moves well beyond the borders of Lake Superior, transported by atmospheric currents northward and eventually deposited into Canadian lakes hundreds of kilometers from the original industrial site (Berndt 2003).

\section{Political concerns and the shift to Labrador iron ore}

When high-grade ore supplies in the Lake Superior district appeared to be dwindling after the Second World War, American steel companies set out not just to develop taconite in Minnesota, but also to secure significant supplies of high grade iron ores from other countries. By 1945, American corporations were exploring iron-rich geological 
formations in South America, especially in Venezuela where "the largest known deposit in the western hemisphere" had been located by U.S Steel ("The Iron Ore Dilemma" 1945, 138). Venezuela had enormous deposits of high-grade ore, yet political upheaval, high taxes, and economic policies across much of South America posed problems for US investments in iron development. Moreover, the distance from US steel production centers meant high shipping costs. Even more daunting was the concern that American ore boats might be exposed to enemy submarines in the event of another war. As Fortune Magazine put it: "Foreign ores were rich, but risky," ("The Iron Ore Dilemma" 1945, 17). After the Second World War, a discourse developed in the US about the need to gain secure access to strategic industrial resources abroad. Iron ore was of particular concern. In 1951, US President Harry S. Truman asked CBS chairman William S. Paley to form the Materials Policy Commission to study the nation's needs for natural resources. The commission's 1952 report, Resources for Freedom: Foundations for Growth and Security, echoed the cold war context in which was written (Paley 1952). Couched largely in terms of a brewing battle between capitalism and socialism, the report concluded that the United State's growing demand for resources meant that the nation faced potential strategic conflicts, unless sources could be developed from friendlier partners.

One attractive option was the Quebec-Labrador region of the Canadian subarctic (Figure 2). Although the presence of iron ore deposits in the Quebec-Labrador region had been noted in 1890 by the Geological Survey of Canada, it was not until the early 1940s that these deposits were described in any detail. By the end of the decade large deposits of high grade hematite and lower grade meta-taconite (a metamorphosed version of taconite) 
had been located along the Quebec-Labrador border by two subsidiaries of the Ohiobased Company Hanna Mining Corporation. When the resource proved up in the early 1940s, the Canadian north emerged as a politically stable alternative to South America. Iron ore from the Quebec-Labrador region was important, the Paley Report argued, in part because of the geography of the American steel industry. "With steel industry concentrated in the northeast, the Commission looked to Canada to solve its long-term supply ore problem," (Manners 1971). Labrador Trough ores were not only closer to American steel production centers than South American ores, they would also be easier to defend in the event of another world war. Nor were there any taxes or restrictions on iron exports, which could not be said of South America. The strategic advantages of Canadian iron ore were obvious, so much so that the Paley Report argued for US investment in this region (Paley 1952, Clark-Jones 1987). This meant not only private investment, but also government involvement: "state intervention was not only desirable," the Paley report argued, "but essential to [US] preservation" (quoted in Clarke-Jones 1987). To that end the US government needed to invest not just in the technology needed to exploit low grade taconite, but also the transportation technology needed to move iron ore from the Quebec-Labrador border area. According to Paley, the planned St. Lawrence Seaway (discussed in greater detail below) was important because it would ensure the free flow of Canadian resources, including iron ore, in the event of another world war.

Yet the Labrador Trough still posed significant challenges. Although geographically closer to the American steel mills than the closest South American ores were, in 1945, when Fortune Magazine wrote of the Iron Ore Dilemma in the US, there were no roads or railroads in the Labrador Trough, and thus no way to move the ore to market. Nor were 
there any towns or modern communications, or for that matter a labour force for the mines. Harsh winter weather, moreover, meant that mineral production could only occur for part of the year, whereas South America mines could operate all year long. While US Steel established open pit iron ore mines in South America, Hanna and its partners opted for the Labrador Trough on the grounds that long winters, poor transportation facilities and so on were ultimately less challenging than South American political instability. In a letter to Jules Timmins, Hanna's principle Canadian partner in the iron ore project, Hanna president George Humphrey wrote, "The one great advantage we have over them [U.S Steel and others investing in South America] is the stability of the government of the country in which we are located. If the governments were reversed, I think it would be practicably impossible to get any Americans interested in Labrador ore, but because we have so much confidence in our friends in government in Canada and in the stability of the Canadian government and its economic condition more generally we feel that some other disadvantages as compared to Venezuela can be greatly offset," (Humphrey 1950).

\section{Canadian Mining Incentives}

In 1954, the Iron Ore Company of Canada (IOC) began the first major effort to exploit the iron resources of the Labrador Trough, opening a mine along the Quebec-Labrador border at the new mining town of Schefferville, Quebec. A few years later the IOC developed the much larger Carol Project at Labrador City, which shipped its first load of iron ore in 1962. More mines followed, including (on the Labrador side) Wabush Mines, managed and partly owned by Cleveland-based mining giant Cliff Resources. More than 
a billon tons of iron ore have since been extracted from the IOC's Carol Lake project alone, almost all of it low grade (39\% iron) meta-taconite that had to be refined before shipping (Schiller 2011).

These developments required significant capital, and Canada offered economic incentives to attract American investment. Mining machines and related equipment could be imported into Canada without taxes or duties. No income tax was charged on new mines in the first four years of operation; and thanks to some clever IOC lobbying, every new open-pit the company developed would be considered a new mine rather than an expansion to an existing one, if it could be shown that the deposits in question were otherwise unconnected (Geren and McCullogh 1990). The formula was simple: new pit, new mine, no tax for four years. Provincial royalties were a special fee paid by resource companies for the right to extract public assets, yet mining companies could also claim these royalties as a cost of doing business at the federal level, thus lowering a company's overall tax bill even further. The result of these and other incentives was that mining companies were among the least taxed companies in the country (Bucovetsky 1975, McQuaig 1987).

Concessions were another key incentive for corporations looking to invest. The governments of Quebec and Newfoundland during the 1930s and 1940s offered long term land concessions to local as well as foreign mining and exploration companies, including a 57,000 square kilometer block on the Labrador side alone (Figure 3). According to a commissioned history of the IOC, the Labrador concession was "the last of those giant land grants by which all the great imperial powers of Europe had developed their colonies for hundreds of years" (Geren and McCullough 1990, 33). Mining concessions granted 
exclusive exploration rights over large areas. Concession holders were required to pay a small annual royalty in exchange for exclusive exploration rights. They also had to return to the Crown a certain number of square miles each year, ultimately retaining only those areas that were actually going to be exploited. Concession holders also had to spend a certain amount of money each year on exploration or again the concession area would revert to the crown.

In 1939 the Quebec government granted McKay Quebec Explorers Company a mining concession comprising 10,000 square kilometers. Around the same time the Newfoundland Commission of Government (which administered Newfoundland and Labrador from 1934 until confederation with Canada in 1949) granted a company called Weaver Coal a massive 57,000 square kilometer concession in Labrador. A few years later this concession was acquired by the Labrador Mining and Exploration Company. Both concessions were eventually acquired by Ontario mining magnate Jules Timmins who then formed a partnership with Cleveland's M.A Hanna Mining and others in order to raise the capital needed develop the region's rich iron ore resources (Boutet 2014, Neal 2000, Summers 1994).

While some politicians complained that the concession system might preclude competition, most agreed that the provinces needed mining, and mining needed capital. In Newfoundland, mining and other land-based industrial activities had long been portrayed as a panacea for unemployment and economic development outside the fishery (Cadigan 2009). Joseph Smallwood, Newfoundland's first premier, said in a 1950 speech: "It is a vast new industrial empire that is opening up in Labrador, nothing less." Mining would not only "virtually wipe out unemployment," but also possibly lead to a "manpower 
shortage within three to four years." According to Smallwood, the province was set "for an era of very real development" (Smallwood n.d.). Mining employment was important to Quebec politicians too, but plans to develop iron mines also reflected a nationalist political discourse, even though the mines themselves were largely owned by private American interests, that tied northern resource development to Quebec's politicaleconomic independence, (Bradbury 1985, Boutet 2014, Desbiens 2013).

Concessions conferred huge advantages to those who obtained them. Nevertheless, Timmins wanted more than just exclusive exploration rights. In a 1946 letter to the Commission of Government, he made 15 additional requests, including a "free, feesimple grant of land for a railway (needed to move the ore to market), and all necessary branches, stations, town-sites, hotels, and other required buildings; freedom for all customs duties on all equipment, plant supplies, and materials required for the construction, maintenance and operation of the company's undertakings; freedom from all government, municipal, and local taxation; the right to take free of royalty from crown land all the timber needed for the construction, maintenance, and operation of the company's undertakings; the right to develop free of royalty all water power" on whatever rivers seemed best suited to the task; and even "exclusive fishing and hunting rights in the country surrounding the hotels, tourist lodges and holiday resorts which the company would erect to encourage passenger traffic over the railway." He also asked that no other railway be allowed in the area, unless it was absolutely necessary for some other purpose, and even then only if all the land for it was purchased outright (Timmins to Neill 1946). 
It was a measure of the Commission of Government's eagerness for new developments in Labrador that much of this was granted, albeit after much debate and usually in modified form. One representative felt that Timmins' requests were not only excessive in some cases (particularly when it came to water rights), but also "premature" in that the financing for the mines, as far as he had ascertained, had not yet been finalized (Commission of Government 23/11/1946). Another member of the government agreed that water rights for mining should be limited, but insisted nonetheless in regards to timber rights "that it would be short-sighted policy on our part if by insisting on the payment of royalties and lease rentals we held up a major industrial development." In his view "we should do everything, within reason of course, to encourage them" (Commission of Government, 5/12/1946). Ultimately, the tax and duty provisions were limited to particular kinds of activities for specific periods of time, and all earnings from iron mining would be taxable. Rather than fee-simple land grants across the board, some fee-simple land along with term-limited leases and annual fees were offered. A rental fee of one-dollar per square mile was applied to all timber lands, and any wood exported was subject to a royalty of four dollars per 1000 board feet. Otherwise, the company could use however much timber it needed to construct the railway. As for water rights, the mining company would be limited to just one river, and not the one it wanted; the company would pay the government an annual fee of 15 cents per horsepower developed; any surplus power was to be "made available to the public at reasonable rates;" and any exports of power to nearby Quebec were to be taxed at a negotiated rate (Secretary of Natural Resources, 23/11/1946) . Finally the government agreed not to allow another railway in the area, unless it could be shown that an existing railway was insufficient for 
some new purpose, and provided that the mining company was unable to show "good cause" why another railway should be refused (Statutes of Newfoundland, 1948). Only exclusive hunting and fishing rights were rejected outright.

Mining required not just resources and capital, but also well-defined political borders. Yet well into the post-World War II era, the Quebec-Labrador borderlands remained a contested colonial space. In 1927 the British Privy Council had established the QuebecLabrador border using the "height of land" or "Watershed Doctrine" of international law "by which a seacoast carries with it a right to whole territory drained by rivers which empty their waters into its line" (Cukwurah 1967, 186; Neary 1978). But many Quebec politicians publically rejected the decision, and it was not until the late 1940s that any portion of the border was actually surveyed. Concession holders were not pleased about the uncertainty. But nor were government officials in Ottawa. As one Federal official explained, in a confidential letter to the Commission of Government, "although there are political reasons for postponing the determination of the boundary, there are cogent practical reasons for its determination in relation to mineral concessions on both sides of the border" (Flinn, 1946). What mattered in 1946 was not the east-west flow of water, but rather the east-west flow of taxes and royalties to the governments involved. The precise location of iron ore bodies in relation to the border would determine where the taxes and royalties flowed, as well where labor camps, towns, railroads, and related infrastructure would be located (Hare 1952). But defining the border meant revisiting a divisive political issue, something officials in Ottawa were reluctant to do.

Once the borders were surveyed, however, mining investments could begin in earnest. The first mines focused on hematite near the new mining community of Schefferville. 
Airplanes were used to transport men, machinery, food and all the other supplies needed for a large scale, multi-year construction project, as well all the cement and related building materials and technology needed to generate hydroelectric power on the Menihek River. A 450 kilometer railroad from Schefferville to Sept-Iles on the north shore of the St. Lawrence River was constructed to export the ore. A dockyard and associated shipping infrastructure were constructed at Sept-Iles. As many as 6000 construction-workers contributed to the first phase of the mining project in the late 1940s and early $1950 \mathrm{~s}$.

The impact on land and water was considerable, and as the railway and port and loading facilities at Sept-Iles illustrate, it extended well beyond the mine site. Later reports noted that forest fires had occurred, that gas and oil spills were common, and that waste and garbage littered the landscape along the length of railway (Snowden, 1974). Tremendous amounts of stone and sediment entered rivers and streams as construction crews cut and blasted their way through forest and rock - and all of this before mining even began. Nonetheless, the narrator of a 1950s film promoting the Quebec-Labrador iron mines expressed with pride how the northern Canadian landscape had been conquered by a combination of technology, capital and brute determination. "If you came to a valley, you filled it up. If something was in the way, you pushed it aside." "The cargos were fabulous," he continued. "Tractors, trucks, jeeps, earth movers, drills, snowmobiles, pumps, compressors, generators, cranes, girders, rails, boilers, big brutal machines to crush and batter; small cunning machines to drill, gauge, tighten; a quarter of a million tons of machines to scratch a thin line through the wilderness," ("Iron Ore from the North" n.d.). 
The mines did not just happen. Economic and social policies on both sides of the USCanadian border brought about what historian Paul Josephson calls "brute force technology" to transform landscapes and subsurface ore bodies of Quebec-Labrador borderlands (Josephson 2002). The application of such technology was made possible by complex financial maneuvers. At the heart of the Quebec-Labrador mining operation in the 1950s was the Iron Ore Company [IOC] of Canada, an American company incorporated in Delaware in 1949 and backed by some of the largest iron ore and steel interests in the United States. The Canadian Hollinger Gold Mining Company and its various subsidiary companies were also involved. Capitalized at close to 200 million dollars, the purpose of the company was the development of ore resources mainly for the use of the American steel companies who were its majority owners, although eventually some of this ore would also be sold in Canada and parts of Europe. Spreading this investment across seven iron and steel companies, and several closely-related companies, not only made it possible to undertake mining on a large scale in a distant and poorly connected corner of the North American economy, but also helped to reduce the financial risks involved.

It was not only the provincial governments of Newfoundland and Quebec that encouraged mining investments; the federal governments of Canada and the United States also mobilized state power to promote northern mining. The St. Lawrence Seaway is the clearest example. The Paley Report had argued for a publically funded seaway in Resources for Freedom. American mining companies also used strategic arguments to promote public investment in the Seaway. Hanna Mining president George Humphrey (who served as Secretary of the Treasury in the Eisenhower administration) argued in 
1950 that national security made the Seaway imperative: "The construction of the St. Lawrence seaway is indispensable as a measure of national security and defense...The seaway would give the American steel industry access through protected waterways to the newly-discovered Labrador-Quebec ore deposit.... The nearest other deposits in South America are far away and involve political and transportation problems which may make them again unreliable in time of war, as they quickly proved to be in the last war" ("Iron Ore from the North," n.d.).

Privately, however, economic considerations were just as important to the mining companies as strategic interests, perhaps more so. The Iron Ore Company of Canada, for example, calculated that its shipping costs could be reduced by approximately 92 cents per ton with a publically funded St. Lawrence Seaway. That may not seem like much. Yet when one considers that the company planned to ship a minimum of 10 million tons a year by the late 1950s and perhaps three times as much by the mid-to-late 1970s, the potential savings involved were significant. At 10 million tons, according to another set of calculations, the seaway route would return 19.1 percent on the company’s $\$ 200$ million investment ("Iron Ore and the St. Lawrence Seaway Proposal," n.d.). Iron mining was not only the reason the seaway was constructed, of course (MacFarlane 2014). Midwestern grain, for example, accounted for more than half of all downriver traffic after 1959 (Wynn 2007). Similarly, the Seaway expanded the economy of the Lake Superior district beyond its focus on mining. Duluth became the Great Lake's largest port, shipping grains, coal, and other American products from the interior to international markets (Duluth Seaway Port Authority, no date). Iron was important, however. Along 
with grain it accounted for some 70 percent of shipments on the seaway by the early 1970s (Jenish 2009).

\section{Conclusion}

Iron ore mining in the eastern Canadian subarctic and Lake Superior Basin shaped each other, and both were shaped by global processes and concerns. While one mining area (Labrador) is much further north than the other, both lie at the northern edges of their respective countries. For centuries, urban centers of power framed northern peripheries as uninhabited and remote, hoping thereby to promote colonization of these regions for their resources. Yet both places are long-inhabited landscapes where Indigenous and Aboriginal peoples have lived since the retreat of the ice thousands of years ago. In both regions, as across the north, Indigenous peoples and their land tenure rights were rendered invisible in discussions of mine development—a topic deserving of a full essay. New iron mines continue to be justified by a similar colonial logic, even as both the Innu and Anishinabeg have resisted, and continue to resist, the problematic legacies of mining. Labrador Trough iron production began not to feed the needs of Canadian markets, but rather to assuage American fears of depletion on its own iron ranges in the Lake Superior district $1700 \mathrm{~km}$ away. Those depletion fears were partly shaped by the needs of the booming American automobile industry, and by domestic manufacturing more generally. But they were equally influenced by Cold War anxieties. From the perspective of people such as Paley, the US needed secure sources of iron ore to combat communism. The same concerns and anxieties encouraged the shift from hematite to taconite mining within the Lake Superior Basin. 
Mines implied markets, which in turn implied profits. Yet there was nothing natural or inevitable about a market for either Lake Superior Basin taconite or subarctic hematite. Instead these markets had to be cultivated. As historian Richard White writes, "there is such thing as a market set apart from particular state policies, institutions, and social and cultural practices. The question is not whether governments shape markets; it is how they shape markets" (White 2011, xxv). The myth of private enterprise was that somehow the iron mining companies had done all of this work themselves. But markets for QuebecLabrador hematite and meta-taconite and Lake Superior taconite were encouraged, even created, with the help of the state at a variety of scales: nationally funded geological research, new tax incentives for mining companies, massive land and water concessions, and the construction of transportation infrastructure all encouraged new developments. The St. Lawrence Seaway is perhaps the most obvious example, but even the railroads out of Quebec-Labrador, built by the IOC in the late 1940s early 1950s, depended on land grants from Quebec and Newfoundland. All of these incentives, and more besides, helped to create markets for taconite and hematite ores that previously had little or no economic value. What was profitable to mine in the 1950s had not always been profitable, but was made so, in part by the actions of states across scales.

Markets alone were no guarantee that mines would be built, however. Massive open pit mines have enormous overhead costs for machinery, transportation, labor, the creation of 'company towns' in 'remote' and often sparsely settled areas, and much else besides. Establishing iron mines thus entailed a massive mobilization of financial capital, not just nationally but also across national borders. The Iron Ore Company of Canada was an American company, incorporated in Delaware in 1949. Likewise, Cliffs Natural 
Resources operated within the Labrador Trough, but like IOC it was an American corporation, that also took the lead in developing the Lake Superior District's taconite resources. Even in the first half of the twentieth century, when flows of finance were less global, mining was still multinational. A person could be completely oblivious to mining in Quebec-Labrador and the Lake Superior Basin, but still at some level still be connected to it because he or she happened to purchase insurance from one of the companies that helped to finance the mines there.

Open pit mines represent intensely local transformations of nature. But we can focus on the local to fault if we ignore the broader contexts in which all mines are embedded. From flows of state power, to flows of capital and flows of technology, events across scales shaped the most local processes in both Quebec-Labrador and the Lake Superior Basin. Moreover, the effects of iron mining extended well beyond the mine site, cutting across scales of time and space. Mines and their effects may appear remote and selfcontained when viewed from afar, or in isolation, but their histories bear out more complicated, transboundary stories.

\section{Acknowledgements}

This paper emerged out of a workshop on Extractive Industries and the Arctic organized by Arn Keeling and John Sandlos with assistance from the Rachel Carson Center and Memorial University. We would like to thank Dag Avango, Alla Bolotova, Gavin Bridge, Paul Josephson, Arn Keeling, Mark Nuttall, Richard Powell, Andrea Proctor, John Sandlos, and Frank Tester for their comments at the workshop stage, as well as two anonymous peer reviewers who provided helpful comments and suggestions at the publication stage. This work was supported by the Labrador Institute of Memorial University, and by the National Science Foundation Grant \#R56645, Toxic Mobilizations: Iron Mining Contamination.

REFERENCES:

Anon. 1946. Letter, federal official to prime minister's office. Provincial Archives of Newfoundland and Labrador, GN 38 Box 2-1-5 File 9. 
Berndt, Michael. 2003. Mercury and Mining in Minnesota. Mineral Coordinating Committee Final Report. MN Department of Natural Resources, Division of Lands and Minerals, Reclamation Section.

Berndt, Michael E., and William C. Brice. 2008. The origins of public concern with taconite and human health: Reserve Mining and the asbestos case. Regulatory Toxicology and Pharmacology: RTP 52 (1 Suppl): S31-39.

Boutet, Jean-Sébastien. 2014. Opening Ungava to Industry: a decentring approach to indigenous history in subarctic Quebec, 1937-54. Progress in Human Geography, 21, 7997.

Bowlus, W. Bruce. 2010. Iron ore transport on the Great Lakes: The Development of a delivery system to feed american industry. Jefferson, N.C: McFarland.

Bradbury, John. 1985. The rise and fall of the fourth empire of the St. Lawrence: the Quebec-Labrador Iron Ore Mining Region, Cahiers de géographie du Québec, 29, 78, 351-364.

Bucovetsky, M W. 1975. The mining industry and the great tax reform debate, in: A. Paul Pross (Ed.), Pressure Group Behaviour in Canadian Politics McGraw-Hill Ryerson, Scarborough, 106.

Cadigan, Sean Thomas. 2009. Newfoundland and Labrador: A History, University of Toronto Press, Toronto.

Commission of Government, 1946. Report dated 23/11/1946. Provincial Archives of Newfoundland and Labrador. Provincial Archives of Newfoundland and Labrador.

GN3_2 Natural Resources Box 104 File 546_1 Labrador Mining and Exploration Co_Vol 11946.

Commission of Government 5/12/1946. Report dated 5/12/1946. Provincial Archives of Newfoundland and Labrador. GN3_2 Natural Resources Box 104 File 546_1 Labrador Mining and Exploration Co_Vol 11946.

Chesley, AJ, Secretary. 1947. Minnesota Department of Conservation, In The Matter of the Application of Reserve Mining Company for Certain Permits in Connection with Proposed Taconite Iron Ore Beneficiation Operations near Beaver Bay in Lake County, Minnesota. 117.G.17.1 Minnesota. Attorney General. Natural Resources Division. Reserve Mining Company Files. Minnesota Historical Society. State Archives.

Clark-Jones, Melissa. 1987. A Staple State: Canadian Industrial Resources in the Cold War. University of Toronto Press, Toronto.

Cukwurah, O. 1967. The settlement of boundary disputes in international law. Manchester University Press, Manchester. 
Davis, E. W. 1947. Statement in Support of Reserve Mining Company Application for Permit, Hearing Transcript Summary, July 1947 Hearing. 117.G.17.1. Minnesota. Attorney General. Natural Resources Division. Reserve Mining Company Files. Minnesota Historical Society. State Archives.

Davis, E. W. 2004. Pioneering with Taconite: The Birth of a Minnesota Industry. Minnesota Historical Society Press.

Desbiens, Caroline. 2013. Power From The North: Territory, Identity, And The Culture Of Hydroelectricity In Quebec, UBC Press.

Duluth Seaway Port Authority, http://www.duluthport.com/ accessed 4/6/15

Edstrom, H W and D M Rice. 1982. "Labrador lung": An unusual mixed dustpneumoconiosis. Canadian Medical Association Journal 126 (1), 27-30.

Ewing, Ann. 1950. Low-Grade ore yields iron. The Science News-Letter 57 (20), 314315.

Flinn W.H. 1946. "Labrador Boundary: Memorandum for Commission of Government. 23, May, 1946. Provincial Archives of Newfoundland and Labrador. GN 38 Box 2-1-5 File 9.

Geren, Richard and Blake McCullogh. 1990. Cain's Legacy: The Building of the Iron Ore Company of Canada. Iron Ore Company of Canada.

Hare, F Kenneth. 1952. The Labrador frontier, Geographical Review, 405-424.

Hayter, R., Barnes, T. J. and Bradshaw, M. J. (2003), Relocating resource peripheries to the core of economic geography's theorizing: rationale and agenda. Area, 35: 15-23.

Harrison, H Stuart. 1953. Where is the iron ore coming from?, The Analysts Journal 98101.

Humphrey, George. 1950. Letter, George Humphrey to Jules Timmins, 27 March 1950. Joseph Smallwood Papers, File 3-20-057 Memorial University of Newfoundland Archives.

"Iron Ore Dilemma." 1945. Fortune Magazine.

"Iron Ore From the North." No date. Labrador Institute Film Archive.

"Iron Ore and the St. Lawrence Seaway Proposal" No date. Library and Archives Canada RG18 vol 183 file r-30-3. 
Jenish. D'Arcy. 2009. The St. Lawrence Seaway: 50 Years and Counting. Penumbra Press.

Jorgensen, Dolly and Sverker Sorlin. 2013. Introduction: Making the Action Visible, Making Environments in Northern Landscapes, in Northscapes: History, Technology, and the Making of Northern Environments, UBC Press, Vancouver, BC.

Josephson, Paul. 2002. Industrialized Nature: Brute Force Technology and the Transformation of the Natural World, Island Press, Washington.

Kakela, Peter J. 1978. Iron ore: Energy, labor, and capital changes with technology, Science 202 (4373), 1151-1157.

LeCain, Timothy. 2009. Mass Destruction: The Men and Giant Mines That Wired America and Scarred the Planet, Rutgers University Press, New Brunswick.

Lourey, Tony, Kathy Sheran, Tim Mahoney, Sheldon Johnson, Tom Huntley, and Tina Liebling. 2013. Annual Report To The Legislature Minnesota Taconite Workers Health Study. St Paul, MN.

MacFarlane, D. Negotiating a River: Canada, the US, and the Creation of the St. Lawrence Seaway. UBC Press. 2014.

Mancke, Richard B. 1972. Iron ore and steel: a case study of the economic causes and consequences of vertical integration, The Journal of Industrial Economics 20 (3), 220229.

Manners, Gerald. 1971. The Changing World Market for Iron Ore, 1950-1980: An Economic Geography, John's Hopkins Press, Baltimore.

Manuel, Jeffrey T. 2013. Mr. Taconite: Edward W. Davis and the promotion of lowgrade iron ore, 1913-1955. Technology and Culture 54 (2), 317-345.

McQuaig, Linda. 1987. Behind Closed Doors: How The Rich Won Control Of Canada's Tax System And Ended Up Richer, Viking, Markham.

Minnesota Department of Health. 1957. Lake Superior Study 1956 and 1957. 117.G.17.5B Minnesota. Attorney General. Natural Resources Division. Reserve Mining Company Files. Minnesota Historical Society. State Archives.

Mount, Donald. 1973. Studies Regarding the Effect of the Reserve Mining Company Discharge on Lake Superior. Washington, D.C: Government Printing Office.

MPCA (Minnesota Pollution Control Agency) 1973. Memorandum on Studies of Asbesti-Form Minerals in Waters of Lake Superior Basin July 3, 1973. 117.G.18.4F III-4. 
Minnesota. Attorney General. Natural Resources Division. Reserve Mining Company Files. Minnesota Historical Society. State Archives.

Montague, Mr. 1947. Transcript of Proceedings Re: Application for Permit to Appropriate Water from Lake Superior, Before Chester S. Wilson, Commission of Conservation. June 17, 1947. St. Paul, Minnesota. 117.G.17.1. Minnesota. Attorney General. Natural Resources Division. Reserve Mining Company Files. Minnesota Historical Society. State Archives.

Neal, H.E. 2000. Iron deposits of the Labrador Trough. Exploration Mining Geology 9 (2), 113-21.

Neary, Peter. 1978. Newfoundland and Quebec: Provincial neighbours across an uneasy border. Journal of Canadian Studies, 2 (2), 35-51.

Paley, William S. 1952. Resources for Freedom: Report of the President's Materials Policy Commission, United States Government Printing Office, Washington.

Reserve Mining Company. 1947. Summary of Evidence as Presented by Reserve Mining Company in Support of Application for Permit to Construct Harbor Facilities.

117.G.17.1. Minnesota. Attorney General. Natural Resources Division. Reserve Mining Company Files. Minnesota Historical Society. State Archives.

Reynolds, Terry S. and Virginia P. Dawson. 2011. Iron Will: Cleveland-Cliffs and the Mining of Iron Ore, 1847-2006, Wayne State University Press.

Secretary of Natural Resources, 1946. Report dated 23/11/1946. Provincial Archives of Newfoundland and Labrador. GN3_2 Natural Resources Box 104 File 546_1 Labrador Mining and Exploration Co_Vol 11946.

Schiller, Edward. 2011. Canada's labrador and newfoundland/quebec iron ore mines expand production. Resource World Magazine 74-77.

Smallwood, Joseph. n.d. Speech. Joseph Smallwood Papers, File 3-20-057 Memorial University of Newfoundland Archives.

Snowden, Donald. 1974. Report of the Royal Commission on Labrador. Government of Newfoundland and Labrador.

Statutes of Newfoundland, 1948. An Act Respecting Construction of a Railway in Labrador, 7 February 1948, St. JOhn's 10-27.

Stoddard, Charles. 1968. Special Report on Water Quality of Lake Superior in the Vicinity of Silver Bay. 117.G.17.9 Box II-8. Minnesota. Attorney General. Natural Resources Division. Reserve Mining Company Files. Minnesota Historical Society. State Archives. 
Summers, Valerie. 1994. Regime Change in a Resource Economy: The Politics of Underdevelopment in Newfoundland since 1825, Breakwater, St. John's.

Timmins, Jules. 1946. Letter to James Neill, 28 October 1946 Provincial Archives of Newfoundland and Labrador, GN3_2 Natural Resources Box 104 File 546_1 Labrador Mining and Exploration Co_Vol 1 1946-47.

Tuskey, Frank. 1947. Summary of Testimony July 11, 1947 Re: Reserve Mining Company Application for Permits. Statements in Opposition. 117.G.17.1. Minnesota. Attorney General. Natural Resources Division. Reserve Mining Company Files. Minnesota Historical Society. State Archives.

USGS. 2014. Mineral Commodity Summaries. http://minerals.usgs.gov/minerals/pubs/mcs/

White Richard. 2011. Railroaded: the transcontinentals and the making of modern America. Norton. New York.

Wynn, Graeme. 2007. Canada and Arctic North America: An Environmental History ABC-CLIO, Santa Barbara.

Zwick, David, and Marcy Benstock. 1971. Water Wasteland: Ralph Nader's Study Group Report on Water Pollution. New York: Grossman Publishers. 